\title{
ANP32A wt Allele
}

National Cancer Institute

\section{Source}

National Cancer Institute. ANP32A wt Allele. NCI Thesaurus. Code C125586.

Human ANP32A wild-type allele is located in the vicinity of $15 q 23$ and is approximately 42 $\mathrm{kb}$ in length. This allele, which encodes acidic leucine-rich nuclear phosphoprotein 32 family member A protein, is involved in number of cellular processes, including cellular proliferation and differentiation, apoptosis, tumor suppression, inhibition of protein phosphatase $2 \mathrm{~A}$ and acetyltransferases, regulation of mRNA trafficking and stability, and transcriptional repression. 